\title{
Kačerginės vaikų sanatorijos šilumos energijos vartojimo mažinimo galimybès
}

\author{
Jūratė Karbauskaitė \\ Statybinès šiluminès fizikos laboratorija, \\ Kauno technologijos universiteto \\ Architektūros ir statybos institutas, \\ Tunelio g. 60, LT-44405 Kaunas
}

\section{Eugenijus Perednis}

\section{Atsinaujinančiu energijos}

šaltinių laboratorija,

Lietuvos energetikos institutas,

Breslaujos g. 3, LT-44403 Kaunas

El.paštas: saule@mail.lei.lt

\begin{abstract}
Analizuojama Kačerginès vaikų sanatorijos biokuro katilinès darbo efektyvumas ir pagamintos energijos kaštai. Pateikiami pastatų energijos audito ir energijos suvartojimo dedamųjų tyrimo rezultatai. Investicijų atsipirkimo laikas lyginamas su audito, ịvertinančio trejų metų pastatų eksploatavimą, rezultatais. Darbo užmokesčio ir statybinių medžiagų kainų kitimas paveikè investicijų atsipirkimo laiką. Naujai atlikto audito rezultatai parodè, kad tikslinga renovuoti sanatorijos pastatus. Būtina keisti išorès duris, šiltinti pastoges, keisti langus, apšiltinti sienas ir grindis. Parengtos rekomendacijos pirmaeilei ir tolesnei pastatų renovacijai. Analizuojamas saulès kolektorių panaudojimas.
\end{abstract}

Raktažodžiai: biokuras, šilumos ūkis, pastatų konstrukcija, šilumos nuostoliai, temperatūra, pastatų renovacija

\section{IVADAS}

Efektyvesnis energijos suvartojimas ir aplinkos taršos mažinimas kylant energijos kainoms pasidare itin veiksmingas. Tai būtina iggyvendinti viešosios paskirties - sveikatos apsaugos ir švietimo įstaigose, siekiant optimizuoti valstybès išlaidas. Vienas gerų pavyzdžių, kurių patirtis gali būti naudinga visuomenei, yra Kačerginès vaikų sanatorijos šilumos ūkio tobulinimas. Kaip minèta [1], padedant Švedijos nacionalinès energijos agentūrai $2002 \mathrm{~m}$. buvo diegiama integruotos biomasès ir saulès energijos panaudojimo sistema. Šis projektas buvo dalis Švedijos investicinès klimato programos (SICIP), kurios tikslas - igyvendinti projektus, skirtus tobulinti energetikos sektorių ir šitaip mažiau šalinti ị aplinką teršalų, sukeliančių šiltnamio efektą. İdiegus ją, šiluma gaminama ir tiekiama sanatorijos pastatams visiškai panaudojant atsinaujinančiają energiją. Buvo sumontuota automatinè medienos atliekas deginanti katiliné, saulès kolektoriai karšto vandens ruošimui, visuose sanatorijos pastatuose ịrengti nauji šilumos punktai, pakeisti šildymo, karšto ir šalto vandens tinklai. Šių priemonių dèka atlikti darbai leido gerokai sumažinti kenksmingų emisijų lygi, o tai ypač svarbu, kai sanatorijos pacientai yra ịvairiomis ligomis sergantys vaikai.

Priemonès nukreiptos $\mathfrak{i}$ tolesnị pagamintos energijos taupymą, t. y. efektyvų jos panaudojimą įvairios paskirties sanato- rijos pastatuose [2]. Nesandarūs langai ir durys, prastai apšiltintos pastogès, išorinès sienos su maža šilumine varža buvo ir yra pagrindiniai šilumos nuostoliu šaltiniai. Energijos auditas buvo atliktas 2005 m.,pagal jị parengtas Kačerginès sanatorijos pastatų rekonstrukcijos planas. Energijos auditas patikslintas 2008 m., pasikeitus ekonominėms sąlygoms ir techniniams reikalavimams bei įvertinus atliktų priemonių efektyvumą.

\section{METODIKA IR DUOMENŲ ANALIZĖ}

Projektine pastatų šilumos galia ir projektinis energijos suvartojimas šildymui, tenkantis ploto vienetui $\mathrm{kWh} / \mathrm{m}^{2}$, patikslintos faktinès suvartojimo vertès, remiantis 2005-2007 m. kuro suvartojimo duomenimis, pateikiami 1 lentelèje.

$2005 \mathrm{~m}$. patikslinta šilumos šaltinio galia buvo apie $25 \%$ mažesnè nei realiai tuo metu reikèjo šilumos galios, nes pastatai eksploatuojami jau daugiau kaip 40 metų. Per tuos metus langų ir durų sandarumas pablogėjo, atitvarų šiluminė varža atitiko statybos laikotarpio reikalavimus, t. y. šiuo metu nepateisinamai maža.

Pagrindinis kuras yra medienos pjuvenos ir medžio skiedros. Jas ị Kačerginès vaikų sanatoriją tiekia iš netoliese, Ežerèlyje, esančios medžio apdirbimo įmonès. 2 lentelëje pateikiami per pastaruosius metus sudeginto kuro kiekiai ir išlaidos jo igijiimui. Pažymètina, kad kuro kaina pakilo maždaug 50 \% 
1 lentelè. Sanatorijos pastatų šilumos galia ir santykinis energijos suvartojimas

\begin{tabular}{cccc}
\hline Rodiklis & Projektinè vertè & Patikslinta verté 2005 m. & 2005-2007 m. faktinis vidurkis \\
\hline Šildymo galia kW & 410 & 530 & 460 \\
\hline Energijos suvartojimas šildymui kWh/m² per metus & 520 & 610 & 560 \\
\hline $\begin{array}{c}\text { Energijos suvartojimas karštam vandeniui ruošti } \\
\text { kWh/lovadieniui per metus }\end{array}$ & - & - & 140 \\
\hline
\end{tabular}

2 lentelè. Kuro suvartojimas ir išlaidos kurui 2005-2007 m.

\begin{tabular}{|c|c|c|c|}
\hline Metai & Suvartota kuro erdm & Išlaidos kurui Lt & Kuro kaina Lt/erdm \\
\hline 2005 & 2200 & 43100 & 19,65 \\
\hline 2006 & 2280 & 44300 & 19,42 \\
\hline 2007 & 2330 & 58400 & 25,10 \\
\hline
\end{tabular}

tik per pastaruosius metus. Todèl šilumos energijos taupymo perspektyvos atrodo labai patraukliai. İvertinus saulès kolektorių sukaupiamą šilumą, iš 3 lentelèje pateikiamų duomenų galima teigti, kad nepaisant išorès oro sąlygų kitimo, metinis šilumos poreikis gana pastovus. Saulès kolektoriai šiuo metu gali patenkinti tik maždaug $4 \%$ šilumos poreikių.

Analizuojant kuro ir šilumos ùkio eksploatacijos išlaidas (4 lentelè), matyti, kad kuro dedamoji sudaro apie $40 \%$, ir santykis, nors neturi nepastovios tendencijos, ateityje neturètų gerokai sumažèti. I šių išlaidų analizę neįtraukta elektros energija, suvartojama katilinès ir šilumos ūkio reikmèms, nes neįmanoma atskirti kiekių be apskaitos prietaisų, bei išlaidos atsarginėms dalims ir remontui.

Ateityje numatomos išlaidos šilumos energijai turètų sumažèti, nes jau įdiegtos taupymo priemonès pradeda reikštis. Toliau ypač daug dėmesio turètų būti skiriama mokyklos, gyvenamujuc patalpų ir gydymo bei fizioterapijos pastatų atnaujinimui, atsižvelgiant i $i 3]$ nuostatas.

Energijos suvartojimo tyrimams šilumos tiekimo vamzdyne buvo sumontuoti energijos skaitikliai (1 pav.) Suvartotos

3 lentelè. Pagaminta šilumos 2005-2007 m.

\begin{tabular}{|c|c|c|c|c|c|c|}
\hline \multirow{2}{*}{ Metai } & \multirow{2}{*}{$\begin{array}{c}\text { Pagaminta šilumos, } \\
\mathbf{Q}_{g^{\prime}} \text { MWh }\end{array}$} & \multirow{2}{*}{$\begin{array}{c}\text { Gauta saulès šilumos, } \\
Q_{s}, M W h\end{array}$} & \multirow{2}{*}{$\begin{array}{l}\text { Iš viso suvartota šilumos, } \\
Q_{t}, M W h\end{array}$} & \multicolumn{3}{|c|}{ Sklaida \% } \\
\hline & & & & $\mathbf{Q}_{q}$ & $\mathbf{Q}_{\mathrm{s}}$ & $Q_{t}$ \\
\hline 2005 & 884,47 & 32,98 & 917,45 & 3,44 & 6,03 & 3,53 \\
\hline 2006 & 844,06 & 30,88 & 874,94 & $-1,28$ & $-0,72$ & $-1,26$ \\
\hline 2007 & 836,6 & 29,45 & 866,05 & $-2,16$ & $-5,32$ & $-2,27$ \\
\hline Vidurkis & 855,0 & 31,1 & 886,1 & & & \\
\hline
\end{tabular}

\section{4 lentelè. Išlaidų kurui ir eksploatacijai išklotinė}

\begin{tabular}{|c|c|c|c|c|c|c|}
\hline \multirow{2}{*}{ Metai } & \multirow{2}{*}{ MWh gauta } & \multicolumn{2}{|c|}{ Išlaidos Lt } & \multicolumn{2}{|c|}{ Išlaidos Lt/MWh } & \multirow{2}{*}{$\begin{array}{l}\text { Kuro ir eksploatacijos } \\
\text { išlaidų santykis }\end{array}$} \\
\hline & & kurui & ekspl. & bendros & kuro dedamoji & \\
\hline 2005 & 917,5 & 43120 & 69000 & 122,20 & 35,08 & 0,385 \\
\hline 2006 & 874,9 & 44310 & 76700 & 138,31 & 34,67 & 0,366 \\
\hline 2007 & 866,1 & 58410 & 78600 & 158,19 & 44,82 & 0,426 \\
\hline Ateityje & & & & 121,16 & 67,85 & \\
\hline
\end{tabular}

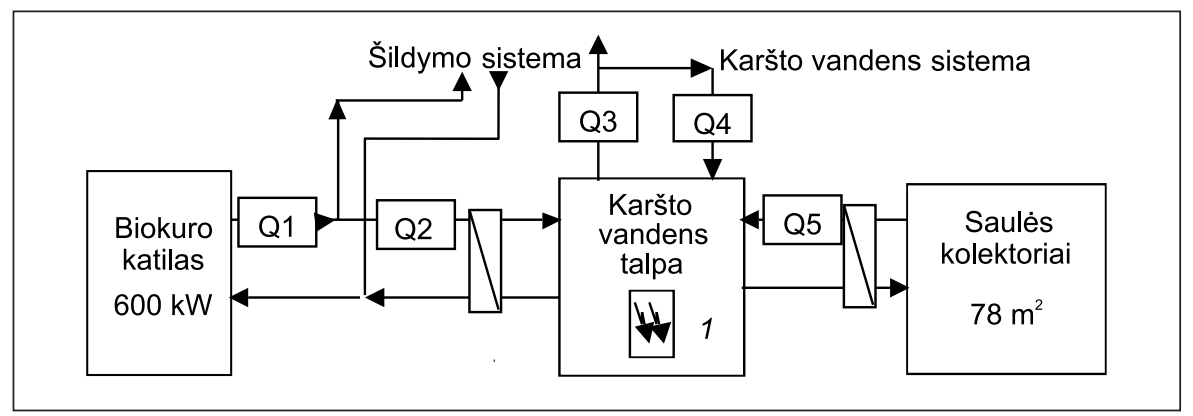

1 pav. Šilumos kiekio matuoklių išdèstymo šilumos energijos gamybos biokuro katilinëje ir saulès kolektoriuose schema. Q1 - visos pagamintos biokuro katile šilumos energijos matuoklis, Q2 - šilumos, tiekiamos į karšto vandens šilumokaiți, energijos matuoklis, Q3 - karšto vandens, tiekiamo sanatorijos pastatams, energijos matuoklis, Q4 - recirkuliacinės karšto vandens tiekimo linijos energijos matuoklis, 05 - karšto vandens, pagaminto saulès kolektoriuose, šilumos energijos matuoklis, 1 - elektrinis kaitintuvas (6 kW) 
5 lentelè. Šilumos energijos suvartojimo išklotinè 2005-2007 m.

\begin{tabular}{|c|c|c|c|c|}
\hline \multicolumn{4}{|c|}{ Šilumos suvartojimas MWh } & \multirow{2}{*}{ Šiluma iš saulès kolektorių MWh } \\
\hline Iš viso & šildymui & karšto vandens ruošimui & karšto vandens cirkuliacijai & \\
\hline \multicolumn{5}{|c|}{2005} \\
\hline 884,47 & 714,73 & 169,74 & 93,64 & 32,98 \\
\hline \multicolumn{5}{|c|}{2006} \\
\hline 844,06 & 693,6 & 150,47 & 101,63 & 30,88 \\
\hline \multicolumn{5}{|c|}{2007} \\
\hline 836,6 & 679,47 & 157,13 & 105,48 & 29,45 \\
\hline
\end{tabular}

energijos šildymui, karšto vandens ruošimui ir tiekimui kiekiai pateikiami 5 lenteleje. Šilumos nuostoliai šildymo vamzdynuose sudaro apie $5 \%$, o karšto vandens tiekimo - apie $40 \%$, įskaitant cirkuliacijos nuostolius.

Energijos suvartojimas karšto vandens ruošimui ir cirkuliacijos palaikymui, kaip matyti 5 lenteleje, yra gana panašus per visus metus, tačiau nuokrypiai nuo vidurkio sudaro 30$70 \%$, atsižvelgus ị metų laiką ir lovadienių skaičių (2, 3 pav.).
Lyginant atskirų metų duomenis, matyti, kad karšto vandens suvartojimas sumažèjo maždaug $15 \%$ per pastaruosius dvejus metus.

Energijos auditų skaičiavimams naudotinas vidutinis energijos suvartojimas per visą analizuojamą laikotarpị.

Energijos suvartojimas šildymui labiausiai priklauso nuo palaikomos temperatūros patalpose ir išorès oro temperatūros, t. y. nuo dienolaipsnių. Dienolaipsnių vertès ir vienerių
2 pav. Karšto vandens (KV) suvartojimas atskirais mènesiais

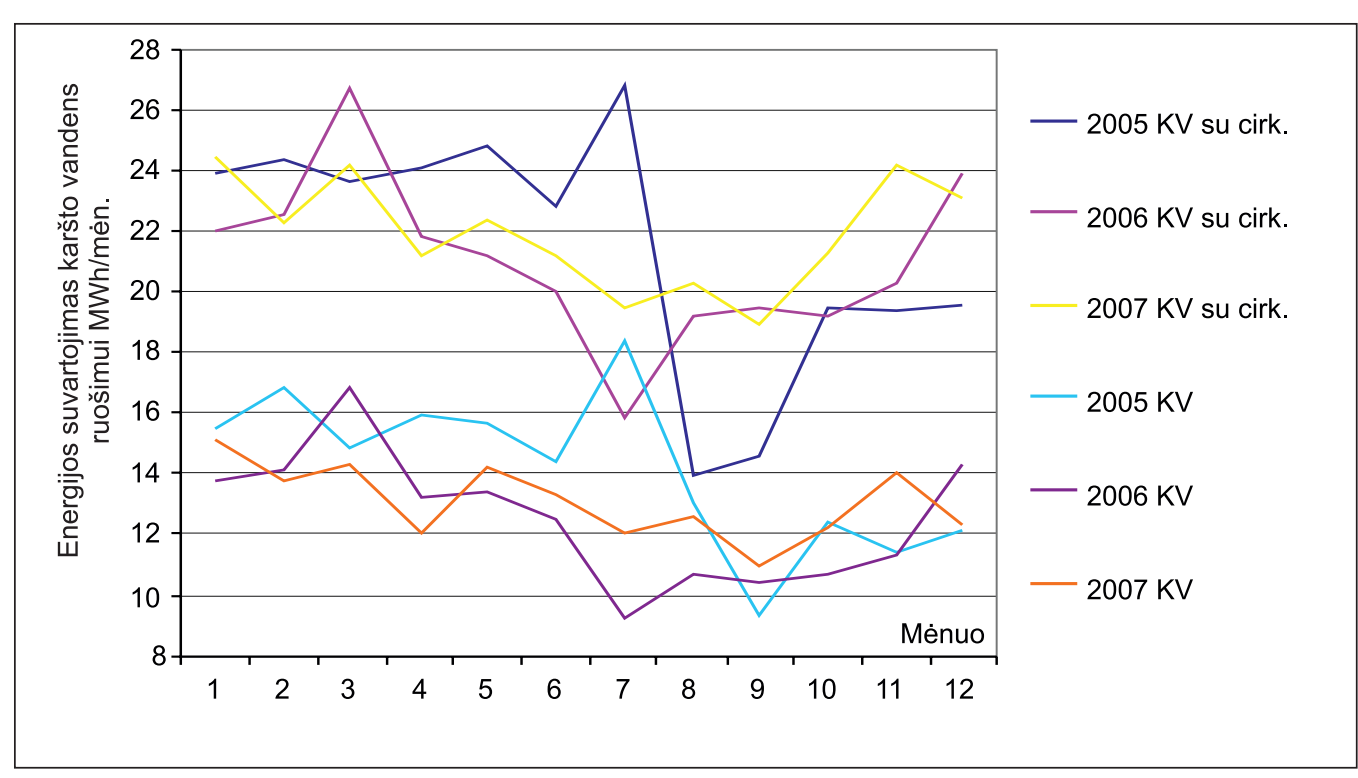

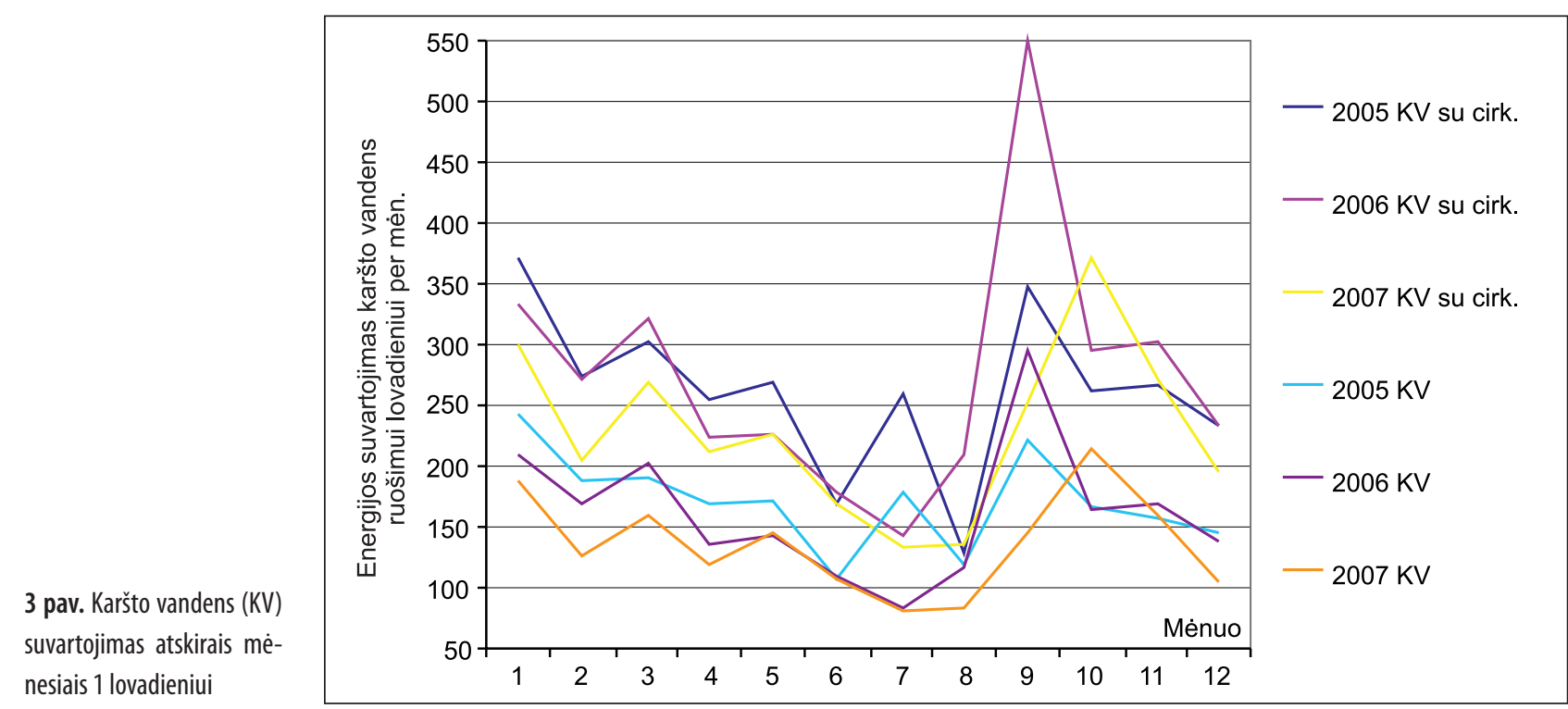

3 pav. Karšto vandens (KV) suvartojimas atskirais mènesiais 1 lovadieniui 
6 lentelè. Šilumos suvartojimas šildymui ir dienolaipsnių vertès

\begin{tabular}{|c|c|c|c|c|c|}
\hline \multirow[b]{2}{*}{2007 mènuo } & \multicolumn{2}{|c|}{ Dienolaipsniai, kai $t_{v}=20^{\circ} \mathrm{C}$} & \multicolumn{2}{|c|}{ Šilumos suvartojimas per mènesị $\mathbf{k W h} / \mathrm{m}^{2}$} & \multirow{2}{*}{$\begin{array}{l}\text { Faktinis šilumos šildymui suvar- } \\
\text { tojimas dienolaipsniui }(H) \mathrm{W} / \mathrm{K}\end{array}$} \\
\hline & faktiniai & norminiai & faktinis & $\begin{array}{c}\text { perskaičiuotas i } \\
\text { normines sąlygas }\end{array}$ & \\
\hline 1 & 579,7 & 781,2 & 45,82 & 61,74 & 3,29 \\
\hline 2 & 733,6 & 680,4 & 52,43 & 48,63 & 2,98 \\
\hline 3 & 458,8 & 632,4 & 35,93 & 49,52 & 3,26 \\
\hline 4 & 388,5 & 426 & 40,17 & 44,04 & 4,31 \\
\hline 5 & 198,4 & 235,6 & 8,45 & 10,03 & 1,77 \\
\hline 6 & 68,2 & 130,2 & 0,29 & 0,55 & 0,18 \\
\hline 7 & 89,9 & 96,1 & 0,18 & 0,20 & 0,085 \\
\hline 8 & 46,5 & 111,6 & 0,18 & 0,44 & 0,164 \\
\hline 9 & 216 & 243 & 8,88 & 9,99 & 1,71 \\
\hline 10 & 384,4 & 399,9 & 24,77 & 25,77 & 2,68 \\
\hline 11 & 573 & 546 & 37,97 & 36,18 & 2,76 \\
\hline 12 & 595,2 & 691,3 & 41,81 & 48,56 & 2,93 \\
\hline Suminiai & 4332,200 & 4973,700 & & rtè $\mathrm{H}_{\mathrm{N}}=$ & 5,0 \\
\hline
\end{tabular}

metų (2007) energijos suvartojimo šildymui išklotinè pateikiama 6 lentelèje. Kaip matyti iš pateikiamų duomenų, yra prielaidų manyti, kad neišlaikomos mikroklimato sąlygos.

Kaip minèta, sanatorijoje yra 9 ịvairios paskirties pastatai. Temperatūra patalpose palaikoma kiek žemesnė nei reikalaujama pagal [4]. Administracijos patalpose temperatūra siekè $16-17{ }^{\circ} \mathrm{C}[2]$. Kituose pastatuose - gyvenamajame, mokykloje ir fizioterapijos, kuriuose vaikai gydosi, mokosi ar ilsisi, vidutinè ménesio temperatūra buvo aukštesnè, nei administracijos pastate, apytiksliai $17-18^{\circ} \mathrm{C}$.

Sanatorijos atitvarų šiluminès savybės pakankamai išsamiai buvo apibūdintos [2], per laiką, praejusị nuo pirminio energijos audito, buvo pakeista nemažai langų, nauji langai sudaro apie $16 \%$, tačiau energijos suvartojimo pokyčio ịvertinti dar negalima (darbai atlikti $2008 \mathrm{~m}$. pavasarį). Irengti modernūs tualetai su grindų šildymu, tačiau šitokių grindų plotas tik apie $4 \%$. Irengtas baseinas gydymo procedūroms. Išorinių atitvarų šiluminès savybės, ịvertinus pokyčius, pateiktos 7 lentelèje.

Visais atvejais patalpose nebuvo palaikoma reikalaujama temperatūra, nes nepavyko. Taigi pastatų renovacijos plètra tampa neišvengiama ir neatidèliotina.

Audito išvados rodè, kad pastatuose pakeitus langus ir duris naujais, papildomai apšiltinus pastoges, įrengus šiuolaikines vėdinimo sistemas, buvo galima 30-50 \% sumažinti šilumos poreikius. Vien dèl šių atitvarų šiluminių savybių pagerinimo būtų i̇manoma sutaupyti bent apie 30-35 \% šilumos. Langų ploto sumažinti nebuvo siūloma dèl higienos reikalavimų.

Naujai atlikto audito rezultatai parodè, kad pasikeitus kuro ir statybos darbų bei medžiagų kainoms, tikslinga apšiltinti išorines sienas, I a. grindis, kitų siūlytų priemonių atsipirkimas irgi ženkliai pasikeitè. Vertinimo pokyčius galima analizuoti pagal 8 ir 9 lentelèse pateikiamus duomenis. 2005 ir 2008 m. pasiūlymai apėmè šias mažų investicijų priemones.

Pažymėtina, kad numatomas pakeisti langų plotas buvo mažesnis, kai kuriose patalpose siūlyta palikti senuosius langus, skalbykloje - senąsias duris. Pertvarkyti vėdinimą irgi buvo numatyta tik valgykloje. Kaip matyti iš duomenų, pakitus per šiuos metus energijos (kuro), statybos darbų ir medžiagų kainoms, bendra investicijų suma padidejo maždaug 1,4 karto, atsipirkimo patrauklumas sumažèjo 1,6 karto. Lyginant ilgai atsiperkančias priemones, darbų kaina gaunasi šiek tiek didesnè, skiriasi jau 1,6 karto, o atsipirkimas pailgëja 1,5 karto, tik darbų sudètis skiriasi. Dabar siūloma apšiltinti išorines sienas, įrengti védinimo sistemas daugumoje patalpų, panaudojant šilumogrąžos įrenginius, bet nebesiūloma iš esmès pertvarkyti šildymo sistemų. Jų atsipirkimas palyginti didelis, atsižvelgiant ị jau modernizuotus šilumos punktus.

Ypač daug dèmesio reikia skirti vėdinimo sutvarkymui, nes pagal normas [7] valgyklos, fizioterapijos ar laboratorijos

7 lentelè. Atitvarų plotai ir šiluminių savybių atitikimas norminėms vertèms

\begin{tabular}{|c|c|c|c|c|c|}
\hline \multirow[b]{2}{*}{ Atitvara } & \multicolumn{2}{|c|}{ Negerinta / nekeista } & \multicolumn{2}{|c|}{ Gerinta / keista } & \multirow{2}{*}{$\begin{array}{l}\text { Norminis šilumos } \\
\text { perdavimo koeficientas } \\
\text { (U) } \mathrm{W} /\left(\mathrm{m}^{2} \mathrm{~K}\right)\end{array}$} \\
\hline & plotas $\mathrm{m}^{2}$ & $\begin{array}{c}\text { šilumos perdavimo } \\
\text { koeficientas }(\mathrm{U}) \mathrm{W} /\left(\mathrm{m}^{2} \mathrm{~K}\right)\end{array}$ & plotas $\mathrm{m}^{2}$ & $\begin{array}{c}\text { šilumos perdavimo } \\
\text { koeficientas }(U) W /\left(m^{2} K\right)\end{array}$ & \\
\hline Išorinès sienos & 1940,3 & 1,04 & - & & \\
\hline Langai & 443,6 & $2,55-2,65$ & 81,3 & 1,9 & 1,6 \\
\hline Durys & 83,2 & $2,5-2,6$ & 3,78 & 1,9 & 1,6 \\
\hline Pastogės perdanga & 2229,8 & 1,2 & - & & \\
\hline Sienos pastogeje & 153,8 & 1,24 & - & & \\
\hline I a. grindų perdanga & 88,8 & 1,25 & 88,8 & 0,44 & \\
\hline
\end{tabular}


8 Ientelè. Pasiūlymų grupè, kai atliekami greičiausiai atsiperkantys renovacijos darbai

\begin{tabular}{|c|c|c|c|c|}
\hline Šilumos taupymo priemonè & Investicijos Lt & Plotas $\mathrm{m}^{2}$ & Šilumos sutaupymas Lt/m. & Atsipirkimo laikas metais \\
\hline \multicolumn{5}{|c|}{2005 m. auditas } \\
\hline Langu pakeitimas & 162880 & 533,7 & 19800 & 8,23 \\
\hline Išorinių durų pakeitimas & 28770 & 76,1 & 20150 & 1,43 \\
\hline Pastogès perdangos apšiltinimas & 96660 & 2182,1 & 55380 & 1,75 \\
\hline Išorinių sienų izoliavimas iš vidaus & 7230 & 144,7 & 1990 & 3,63 \\
\hline $\begin{array}{l}\text { Vidinių sienu, susisiekiančiu su stogu, izoliavimas } \\
\text { iš pastogės pusės }\end{array}$ & 7870 & 157,4 & 3340 & 2,36 \\
\hline Vèdinimo įrangos virtuvèje pakeitimas & 10290 & 121,0 & 85,02 & 8,58 \\
\hline Iš viso & 313700 & & 101860 & 3,1 \\
\hline \multicolumn{5}{|c|}{$2008 \mathrm{~m}$. auditas } \\
\hline Langu pakeitimas & 190730 & 541,7 & 16320 & 11,7 \\
\hline Durų pakeitimas & 58300 & 87,0 & 23400 & 24,9 \\
\hline Pastogės perdangos apšiltinimas & 135300 & 2182,1 & 43050 & 3,1 \\
\hline $\begin{array}{l}\text { Vidinių sienu, susisiekiančiu su stogu, izoliavimas } \\
\text { iš pastogès pusés }\end{array}$ & 15070 & 153,8 & 2540 & 5,9 \\
\hline $\begin{array}{l}\text { Vedinimo ïrangos mokyklos-valgyklos pastate } \\
\text { pakeitimas }\end{array}$ & 34160 & 328,5 & 3870 & 8,8 \\
\hline lš viso & 433600 & & 89180 & 4,9 \\
\hline
\end{tabular}

9 Ientelè. Pasiūlymų grupè, kai atliekami ilgai atsiperkantys renovacijos darbai

\begin{tabular}{|c|c|c|c|c|}
\hline Šilumos taupymo priemonè & Investicijos Lt & Plotas $\mathrm{m}^{2}$ & Šilumos sutaupymas Lt/m. & Atsipirkimo laikas metais \\
\hline \multicolumn{5}{|c|}{$2005 \mathrm{~m}$. } \\
\hline Langu pakeitimas & 162880 & 533,7 & 19800 & 8,2 \\
\hline Išorinių durų pakeitimas & 28770 & 76,1 & 20150 & 1,4 \\
\hline Pastogės perdangos apšiltinimas & 96660 & 2182,1 & 55380 & $1, \bar{u}$ \\
\hline $\begin{array}{l}\text { Vidinių sienu, susisiekiančiu su stogu, izoliavimas } \\
\text { iš pastogès pusès }\end{array}$ & 7870 & 157,4 & 3340 & $2, \dot{\mathrm{e}}$ \\
\hline Grindų apšiltinimas & 380100 & 2100,0 & 24520 & 15,50 \\
\hline Šildymo sistemu pakeitimas & 127600 & 2320,0 & 8900 & 14,3 \\
\hline Virtuvès įrangos atnaujinimas & 25000 & 121,0 & 1640 & 15,2 \\
\hline Vèdinimo įrangos didžiojoje salèje įrengimas & 14690 & 195,8 & 1060 & 13,9 \\
\hline Vèdinimo įrangos virtuvèje pakeitimas & 10290 & 121,0 & 1200 & 8,6 \\
\hline Stogų dangos pakeitimas & 560100 & 3008,0 & & \\
\hline $\begin{array}{l}\text { Lietaus vandens šalinimo nuo stogo } \\
\text { pertvarkymas }\end{array}$ & 12060 & 2320 & & \\
\hline Patalpų po darbų perdažymas & 52200 & 2320 & & \\
\hline Sanitarinių mazgų remontas & 40000 & $8 \mathrm{vnt}$ & & \\
\hline Nuogrindų irengimas & 10130 & 675 & & \\
\hline Ǐ́viso & 1535580 & & 137980 & 11,1 \\
\hline \multicolumn{5}{|c|}{$2008 \mathrm{~m}$. } \\
\hline Langų pakeitimas & 190730 & 541,7 & 16320 & 11,7 \\
\hline Durų pakeitimas & 58300 & 87,0 & 23400 & 24,9 \\
\hline Pastogès perdangos apšiltinimas & 135300 & 2182,1 & 43050 & 3,1 \\
\hline $\begin{array}{l}\text { Vidinių sienu, susisiekiančiu su stogu, izoliavimas } \\
\text { iš pastogės pusès }\end{array}$ & 15070 & 153,8 & 2540 & 5,9 \\
\hline Grindų apšiltinimas & 395630 & & 38860 & 10,2 \\
\hline Išorinių sienų apšiltinimas & 491370 & & 36890 & 13,3 \\
\hline Vèdinimo įrangos pakeitimas & 91370 & & 12080 & 7,6 \\
\hline Iš viso & 1378500 & & 152200 & 9,1 \\
\hline
\end{tabular}

patalpose darbo metu palaikytina atitinkamai nuo 3,6 iki 18 kartų oro apykaita, o orui šildyti tada reikia maždaug tiek šilumos, kiek jos šiuo metu sunaudojama šildymui. Ir miegamujų veddinimui reikia 2,5-kartinès oro apykaitos. Nepalaikant atitinkamų parametrų, gali sumažèti gydymo efektyvu- mas. Vẻdinimo trūkumo sukeliamos problemos mokyklose gana išsamiai analizuojamos [7-9], o sanatorijoje higienos sąlygos ypač svarbios. Irengus šilumogrąžos įrenginius vėdinimo sistemose, galima sugrąžinti, atsižvelgus i patalpų paskirtį, nuo 40 iki $65 \%$ oro šildymui reikalingos šilumos. 


\section{IŠVADOS}

1. Sanatorijos pastatų šildymui, įvertinus atliktus renovacijos darbus, suminis kuro suvartojimas sumažèjo apie $5 \%$, karšto vandens paruošimui - apie $15 \%$, elektros energijos suvartojimas - apie 2,5\%. Didžiausias poveikis gautas, sutvarkius šilumos tiekimo vamzdynus ir šilumos paskirstymo punktus. Atitvarų pagerinta palyginti nedaug (tik pastaraisiais metais, vertinimuose neįtraukta).

2. Renovuojant pastatus pirmiausia būtina keisti išorès duris, langus, šiltinti pastoges ir sienas. Prioritetų seka beveik nepakito per pastaruosius trejus metus, prisidejo grindų apšiltinimas.

3. Reikalaujamam pagal normas mikroklimatui sukurti ir palaikyti būtina suprojektuoti ir ịrengti šiuolaikines vẻdinimo sistemas su šilumogrąžos įrenginiais. Šios priemonès atsipirkimo, patobulèjus ịrangai, trukmé sumažējo apytiksliai vieneriais metais, arba $15 \%$.

4. İrengto saulès kolektoriaus sukaupiamos šilumos kiekis yra panašus, palyginus turimus trejų metų duomenis, ir sudaro $400 \mathrm{kWh} / \mathrm{m}^{2}$ kolektoriaus. Saulès šiluma vasaros laikotarpiu gali dengti apie $30 \%$ šilumos poreikių karštam vandeniui.

5. Siekiant efektyviau vartoti energiją, be pastatų atitvarų renovacijos, reikètų racionaliau naudoti atsinaujinančiujjų šilumos šaltinių išteklius.

Gauta 20110110

Priimta 20110225

\section{Literatūra}

1. Šuksteris V., Perednis E. Monitoring operation of renovated heat production, distribution and consumption systems at Kacergine children sanatorium. 10th International Conference on Solar Energy at High Latitudes NORTH'SUN 2005, Vilnius, Lithuania, May 25, 2005. Vilnius, 2005. P. 1-4.

2. Perednis E., Karbauskaitė J. Kačerginès vaikų sanatorijos šiluminès energijos vartojimas. Energetika. 2006. Nr. 2. P. 63-67.

3. Nacionalinè energijos vartojimo efektyvumo didinimo 2006-2010 metų programa. Patvirtinta Lietuvos Respublikos Vyriausybès 2006 m. gegužès 11 d. nutarimu Nr. 443. Valstybès žinios. 2006. Nr. 54-1956. http://www.ena.lt/ main_veikla_vartojimas.htm

4. HN 42-2004. Gyvenamųjų ir viešosios paskirties pastatų mikroklimatas. Valstybès žinios. 2004. Nr. 105-3911.

5. STR 2.05.01: 2005. Pastatų atitvarų šiluminé technika. 20050318 įsakymas Nr. D1-156. Valstybès žinios. 2005. Nr. 100-3733.

6. STR 2.09.04: 2008. Pastato šildymo sistemos galia. Šilumos poreikis šildymui. $20081022 \mathrm{AM}$ įsakymas Nr. 552.

7. STR 2.09.02: 2005. Šildymas, vèdinimas ir oro kondicionavimas. Valstybès žinios. 2005. Nr. 111
8. Ignatavičius Č., Ignatavičius G., Tuomas E. 1997-2000 metu mokyklu renovacijos rezultatai. Vilnius: Homo liber, 2002. $123 \mathrm{p}$.

9. Jurelionis A., Karbauskaitė J. Renovuotų Lietuvos mokyklų klasių oro kokybė. Energetika. 2005. Nr. 4. P. 42-53.

10. Pikutis R., Šeduikytè L. Technical-economical estimation of the renovated Lithuanian schools. Energetika. 2006. Nr. 1. P. 22-27.

Jūratė Karbauskaitė, Eugenijus Perednis

\section{TRENDS OF ENERGY CONSUMPTION EFFICIENCY AT THE KAČERGINĖ CHILDREN'S SANATORIUM}

Sum $m$ ary

Energy consumption in a biomass boiler room and a renovated heat production at the Kačerginè children's sanatorium are presented according to the energy performance audits. The efficiency of the biomass boiler and energy production costs were determined. Building construction structural elements were investigated and their actual state was evaluated with respect to changes in construction estimates and fuel prices. Pay-back periods of investments are compared in regard to the results of audits carried out within a 3-year period. Changes in labour and material market prices have affected significantly the pay-back of the investments and the benefit of the proposed measures. Recommendations for the renovation of buildings and primary measures are discussed according to changes in economic efficiency. Suggestions on the further development of renewable energy sources are proposed.

Key words: biomass, heat production, building construction, heat losses, renovation of buildings

Юрате Карбаускайте, Эугениюс Переднис

\section{ПЕРСПЕКТИВЫ СНИЖЕНИЯ ПОТРЕБЛЕНИЯ ТЕПЛОЭНЕРГИИ В КАЧЕРГИНСКОМ ДЕТСКОМ САНАТОРИИ}

Резюме

Представлен анализ энергетического аудита и потребления теплоэнергии в Качергинском детском санатории. В зависимости от наружной температуры исследованы эффективность сжигаемого биотоплива и стоимость выработанной энергии. Сроки окупаемости инвестиций сравниваются с результатами аудита, отражающего результаты трехлетней эксплуатации зданий. Изменения заработной платы и цен на строительные материалы значительно повлияли на сроки окупаемости инвестиций и эффективность проведенных мероприятий. Целесообразно провести реновацию зданий. Необходимо менять наружные двери и окна, утеплить чердак, стены и пол. Подготовлены рекомендации для первостепенной и дальнейшей долгосрочной реновации зданий.

Ключевые слова: биотопливное теплохозяйство, конструкция зданий, температура, теплопотери, реновация зданий 